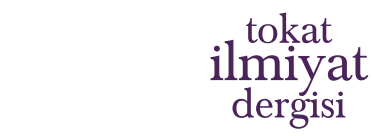

Tokat IImiyat Dergisi | Tokat Journal of IImiyat

9/2 (Aralık | December 2021)

ISSN 2717-6134 | e-ISSN 2717-610X

\title{
Şemsüddîn es-Semerkandî̀nin Beşârâtü̉'lişââât Adlı Eserinin Mantık Bölümünde Burhanî İlimler ve Bilimsel Sorular Konusuna Yaklaşımı
}

\author{
Shams al-Dīn al-Samarqandī’s Approach to the Subject of Burhānī \\ Sciences and Scientific Questions in the Logic Section of his Work \\ Entitled Bashārāt al-Ishārāt
}

\author{
Adem EVMEŞ \\ Dr., Öğretmen Dr., Teacher \\ Milli Eğitim Bakanlığı Ministry of Education \\ Yozgat | Türkiye Yozgat|Turkey \\ ademevmes_71@hotmail.com orcid.org/0000-0001-6934-4221

\section{Makale Bilgisi | Article Information} \\ Makale Türü | Araştırma Makalesi Article Types | Research Article \\ Geliş Tarihi | 01 Ekim 2021 Received | 01 October 2021 \\ Kabul Tarihi | 17 Aralık 2021 Accepted | 17 December 2021 \\ Yayın Tarihi | 30 Aralık 2021. Published | 30 December 2021
}

\section{Atıf | Cite as:}

Evmeş, Adem. “Şemsüddîn es-Semerkandî'nin Beşârâtü'l-işârât Adlı Eserinin Mantık Bölümünde Burhanî ilimler ve Bilimsel Sorular Konusuna Yaklaşımı [Shams al-Dīn alSamarqandī's Approach to the Subject of Burhānī Sciences and Scientific Questions in the Logic Section of his Work Entitled Bashārāt al-Ishārāt]". Tokat ilmiyat Dergisi | Tokat Journal of Ilmiyat 9/2 (Aralık | December 2021), 679-694.

https://doi.org/ 10.51450/ilmiyat.1002956

\section{Intihal | Plagiarism:}

Bu makale, iTenticate aracılığıyla taranmış ve intihal içermediği teyit edilmiştir. | This article, has been scanned by iThenticate and no plagiarism has been detected.

\section{Copyright $\odot$}

Published by Tokat Gaziosmanpaşa University Faculty of Islamic Sciences. Tokat | Turkey. https://dergipark.org.tr/ilmiyat

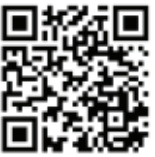




\title{
Shams al-Din al-Samarqandī's Approach to the Subject of Burhānī Sciences and Scientific Questions in the Logic Section of his Work Entitled Bashārāt al-Ishārāt
}

\begin{abstract}
In intellectual history, the annotations written on the main texts of philosophers who had an important place after the creation of philosophical and logical thinking became a tradition. One of the works on which annotations were written during this period is the work of Avicenna's (d. 428/1037) named al-Ishārāt. This work, which is a summary of his philosophy, has been organized in two parts, including logic, physics and metaphysics. The first chapter, which deals with the logic issues, is ten nehic; the second part, which deals with physics and metaphysics, consists of ten namats. Scholars primarily such as Fakhr al-Dīn al-Rāzì (d. 606/1210), Nașīr alDīn al-Ṭūsī (d. 672/1274) and Sayf al-Dīn al-Āmidì (d. 631/1233) wrote annotations on this work. Bashārāt al-Ishārāt written by al-Samarqandī (d. 702/1303) who lived in the second half of the thirteenth century was one of the annotations written on alIshārāt. al-Samarqandī's Bashārāt al-Ishārāt was a noteworthy annotation. Because this work is important in terms of revealing al-Samarqandì's philosophical and logical approach and Avicenna's interpretation of the issues. In this study, we tried to examine al-Samarqandì's views on proof sciences and scientific questions based on the logic section of his annotation by following the commentator method. We fictionalized the annotation via the "qāla- aqūlu" method and cited the al-Ishārāt text as a whole. alSamarqandī annotated all three sections of al-Ishārāt. In the aforementioned annotation, al-Samarqandī made a classification as "namaț" and "nehij" based on Avicenna's sub-headings and followed an arrangement including topics such as "apprehension", "admonition" and "sign" existing within them. In classical logic, the comparison is examined in two sections in terms of its form and item. Comparisons in terms of items are examined in five sections as proof, dispute, rhetoric, poetry and fallacy. While premises expressing the truth create proof, premises not expressing the truth create dispute, rhetoric, poetry and fallacy. Avicenna divided scientific questions into three sections in the first partition and into six sections in the second partition. In the first partition he discussed scientific questions such as "what?", "is it?" and "why?". alSamarqandī examined scientific questions in two sections as primary and secondary. According to al-Samarqandi "what?", "is it?", "why?" and "which?" were primary questions, while "how is it?", "where is it?", "when is it?", "how much?" and "when?" were secondary questions. al-Samarqandī followed Avicenna and made explanations about scientific questions. Sciences have distinctive subjects, principles and issues. Concerning subjects, principles and issues, al-Samarqandī chose to explain Avicenna's statements and contributed to clarifying the subject. al-Samarqandĩ examined sciences in three sections in terms of their subjects, which were "intertwined", "proportional" and "opposite". According to al-Samarqandi the subjects of sciences were named "intertwined" if they were more general than the subjects of specific sciences; "proportional" if sciences had one proportion to each other and only one thing was the subject of two sciences; and "opposite" in a reverse situation. Finally al-Samarqandi discussed the proof types. He divided the proof in question into two as "causality proof" and "existence proof". It should be noted that al-Samarqandī not only explained Avicenna's views, but also included his own views in his commentary.
\end{abstract}

Keywords: Logic, al-Samarqandī, Bashārāt al-Ishārāt, Avicenna, Scientific Questions. 


\section{Şemsüddîn es-Semerkandî'nin Beşârâtü'l-İ̧̧ârât Adlı Eserinin Mantık Bölïmünde Burhanî İlimler ve Bilimsel Sorular Konusuna Yaklaşımı}

Öz: Düşünce tarihinde, felsefî ve mantıkî düşünce oluştuktan sonra önemli yere sahip olan filozofların ana metinleri üzerine yazılan şerhler bir gelenek oluşturmaktadır. Bu dönemde üzerine şerh yazılan eserlerden biri de İbn Sînâ'nın (öl. 428/1037) elİsârât ve't-tenbîhât adlı eseridir. İbn Sînâ'nın felsefesinin özeti niteliğindeki bu eser mantık, fizik ve metafizik konularını içerecek şekilde iki bölümde tertip edilmiştir. Mantık konularının işlendiği birinci bölüm on nehic; fizik ve metafizik konularının işlendiği ikinci bölüm ise on namattan oluşmaktadır. Bu eser üzerine başta Fahreddin Râzî (öl. 606/1210) olmak üzere Nasirüddin Tûsî (ö. 672/1274) ve Seyfeddin Âmidî (öl. 631/1233) gibi âlimler şerh yazmışlardır. 13. yüzyılın ikinci yarısında yaşamış olan Şemsüddin Semerkandînnin (öl. 702/1303), Beşârâtu'l-İşârât adlı eseri de el-Isşârât ve'ttenbîhât üzerine yazılan şerhlerden birisidir. Semerkandînnin Beşârâtu'l-Isşârât' ïnemli bir şerhtir. Zira bu eser Semerkandî̀nin felsefî ve mantıkî yaklaşımını ve İbn Sînâ'nın meseleler üzerine yorumunu ortaya koyması açısından önemlidir. Bu çalışmada Semerkandînnin şerhinin mantık bölümünden hareketle, şârihin metodunu izleyerek burhanî ilimler ve bilimsel sorular üzerine düşüncelerini incelemeye çalıştık. Şerh, "kâle-ekûlu" yöntemiyle kurgulanmış ve el-isşârât metni bütünüyle alıntılanmıştır. Semerkandî, el-isşârât'ın üç bölümünü de şerh etmiştir. Söz konusu şerhte Semerkandî, İbn Sînâ'nın yapmış olduğu alt başlıkları da dikkate alarak "namat" ve "nehc" şeklinde bölümlemeye ve bunların kendi içinde var olan "vehim", tembih" ve "işaret" gibi başlıkları da kapsayacak şekilde sıralamayı takip eder. Klasik mantıkta kıyas, sureti ve maddesi bakımından iki kısımda incelenir. Maddesi bakımından kıyaslar; burhan, cedel, hitabet, şiir ve muğalata olmak üzere beş kısımda incelenir. Yakîn ifade eden öncüllerden burhan meydana gelirken; yakîn ifade etmeyen öncüllerden ise cedel, hitabet, şiir ve muğalata meydana gelir. İbn sînâ bilimsel soruları birinci taksimde üçe ayırırken, ikinci taksimde altı kısımda ele alır. Birinci taksimde "nedir?", "mi?" ve "niçin?" bilimsel soruları ele alınır. Semerkandî ise bilimsel soruları asıl ve furû' olarak iki kısımda inceler. Semerkandî̀ye göre "ne", "mi”, "niçin" ve "hangisi?” asıl soruları oluştururken; "Bu şey nasıldır?" "bu şey nerededir?", "bu şey ne zamandır?" "kaç?" ve "ne zaman?" ikincil soruları oluşturmaktadır. Semerkandî, İbn Sînâ'yı takip ederek bilimsel sorular hakkında açıklamalarda bulunur. Bilimlerin kendilerine özgü konu, ilke ve meseleleri vardır. Semerkandî konu, ilke ve meseleler konusunda İbn Sînâ’nın ifadelerini açıklama yoluna giderek, konunun anlaşılmasına katkı sağlamaktadır. Semerkandî, bilimleri konuları bakımından "mütedâhil", "mütenâsib" ve "mütebâyin" olarak üç kısımda inceler. Semerkandî son olarak burhan çeşitlerini ele alır. Sözkonusu burhan "nedensellik burhanı (burhan-1 limmî)" ve "varlık burhanı (burhan-1 innî)" olarak ikiye ayrılır. Şunu ifade etmek gerekir ki Semerkandî, İbn Sînâ’nın görüşlerini açıklamakla kalmamış, kendi görüşlerine de şerhinde yer vermiştir.

Anahtar Kelimeler: Mantık, Semerkandî, Beşârâtu'l-işârât, İbn Sînâ, Bilimsel Sorular. 


\section{Giriş}

Semsüddîn Muhammed b. Eşref el-Hüseynî es-Semerkandî (öl. 7̧722/1322), 13. yüzyılda yaşamış olan önemli düşünürlerdendir. Hayatı hakkında sahip olduğumuz bilgiler sınırlıdır. Semerkandî nisbesinden onun Semerkand şehrinde doğduğu ve orada yetiştiği anlaşılmaktadır. eș-Șahâa'ifü'l-ilâhiyye adlı kitabının bir nüshasında yer alan nota göre kendisi, 1287 yılında Mardin'de bulunmuş ve öğrencilerin ısrarı üzerine Şerḥu'l-Mukaddimeti'l-Burhâniyye adlı eserini yazmıştır. Yazdığı bu eseri o dönemde Artuklu Sultanı olan Kara Arslan'a sunduğu belirtilmektedir. ${ }^{1}$

Doğum tarihi hakkında kesin bir bilgi bulunmamakla beraber Semerkandî̀nin 1240-1250 yılları arasında doğduğu tahmin edilmektedir. Vefat tarihi ise genel olarak 702/1302 yllı kabul edilmektedir. Ancak Kitâbü'l-Maârif fî Şerhi's-Sahâ'if adlı eserin müstensihi olan Muhammed b. Mahmûd b. Ömer el-Gâzînnin vermiş olduğu tarihlerden yola çıkarak Semerkandî'nin vefat tarihinin 22 Şevval 722/3 Kasım 1322 yılı olduğunu söyleyebiliriz. ${ }^{2}$

Semerkandî için kaynaklarda kullanılan "hakîm", "muhakkık", "allame" vb. isimler onun klasik eğitimi oluşturan alanlarda eser verdiğini gösterir. Söz konusu şârih mantık, kelam, felsefe ve astronomi alanlarında önemli eserler kaleme almıştır. ${ }^{3}$ Semerkandî̀nin bazı eserleri şunlardır: Eşkâlu't-te'sîs, Kıstâsu'l-efkâr fîtahkîki'l-esrâr, el-Mu'tekad li ehli'l-İslâm, esSahâifu'l-ilâhiyye, Âdâbu'l-bahs ve'l-munâzara, Beşârâtü'l-İşârât. ${ }^{4}$ Bu çalışmada Beşârat ve Semerkandî’nin şerh metodu hakkında bilgi vererek konuyu daha anlaşılır kılmaya çalışacağız.

Beşârâtü̈'-Işâarât, Semerkandî'nin el-Işârât ve't-tenbîhât adl eser üzerine yazdığı önemli bir şerhtir. Semerkandî, İbn Sînâ'yı takip ederek eserin bütününü şerh eder. Şerh, "kâle-ekûlu" yöntemiyle kurgulanmış ve el-işsârât metni bütünüyle alıntılanmıştır. Semerkandî, el-Işââât' in üç bölümünü de şerh etmiştir. Söz konusu şerhte Semerkandî, İbn Sînâ'nın yapmış olduğu alt başlıkları da dikkate alarak "namat" ve "nehc" şeklinde bölümlemeye ve bunların kendi içinde var olan "vehim", tembih" ve "işaret" gibi başlıkları da kapsayacak şekilde sıralamayı takip eder.

1 İlhan Kutluer, "Muhammed b. Eşref es-Semerkandî”, Türkiye Diyanet Vakfi İslâm Ansiklopedisi (İstanbul: TDV Yayınları, 2019), 36/475; Şemsüddin es-Semerkandî, İlmü'l-Âfâk ve'l-Enfüs, çev. Yusuf Okşar - İsmail Yörük (İstanbul: Türkiye Yazma Eserler Kurumu Başkanlığı, 2020), (hazırlayanların girişii), 13; ayrıca bk. Ersan Türkmen, "Şemsüddin Es-Semerkandî’nin Beşââtu'lİşârât Adlı Eserinde Kullandığı Şerh Metodu Ve Eserin İlahiyât Bölümünde Varlık Ve İlletleri Konusuna Yaklaşımı", Trabzon İlahiyat Dergisi 6/2 (2019), 235-237.

Semerkandî, ìlmü'l-Âfâk ve'l-Enfüs, 14-16.

3 Mehmet Sami Baga, "el-İşârât "in "Garip" Bir Şerhinin Müellifi: Şemsüddin Semerkandî ve Beşârâtü'l-işârât Adlı Eseri”, Bingöl Üniversitesi İlahiyat Fakültesi Dergisi 3/5 (2015), 226.

4 Kutluer, "Muhammed b. Eşref es-Semerkandî”, 36/477. 
Semerkandî, şerhinde İbn Sînâ'nın görüşlerini ön plana çıkararak, metnin anlaşılır olmasına katkıda bulunmaktadır. Müellif, mantık bölümünün şerhi özelinde daha ziyade Nasîrüddîn et-Tûsî (öl. 672/1274) tarafından yazılan şerhten ve kendi eseri Kıstâsu'l-Efkâr' dan alıntılar yapmaktadır. Aşağıda Semerkandînnin burhanî ilimler ve bilimsel sorular konusuna yaklaşımını ele alacağız.

\section{Semerkandî’nin Mantıkî Yaklaşımı ve Şerhinin Mantık Bölümünde Burhanî İlimler ve Bilimsel Sorular Konusuna İlişkin Örnekler}

\subsection{Maddesi Bakımından Kıyaslar (Beş Sanat)}

Klasik mantıkta kıyas, sureti ve maddesi bakımından incelenmektedir. Kıyasın maddesi bölümünde, kıyasın uygulama alanı olan beş sanat konusu ele alınmaktadır. 'Semerkandî, İbn Sînâ'nın eserinde olduğu gibi beş sanat konusunu dayandığı öncüller bakımından ele alarak, İbn Sînâ'nın ifadelerini daha anlaşılır kılmaya çalışmıştır. Buna göre maddesi ve tasdikî meydana getirmesi bakımdan kıyaslar beş sınıfa ayrılır. Söz konusu kıyasın öncülleri, tasdik ifade etmiyorsa "şiir" olarak isimlendirilir. Kıyas, kesin bir tasdikî ifade etmiyorsa "hitabet", kesinlik ifade eden tasdikin doğru olduğu kabul edilmeyip, çoğunluğun veya hasmın doğru kabul etmesi durumunda ise klyas "cedel" olarak isimlendirilir. Gerçeğe uygun olmayan bir durum ifade edilirse bu duruma "müşâğabe (şağab)" denir. Doğru ve gerçek olduğu kabul edilen kıyaslara "burhan"; doğru ve gerçek olduğu kabul edilmeyen kıyaslara ise "safsata" denir. ${ }^{8}$ Nasîrüddin Tûsî, el-Işârât șerhinde müşâğabe ve safsatanın muğâlatanın altında incelendiğini belirtir. ${ }^{9}$

Beş sanat konusunda ilk olarak burhan incelenir. Şöyle ki burhan, zorunlu, mümkün veya vücudî olması fark etmeksizin doğru öncüllerden meydana gelen kıyastır. ${ }^{10}$ Zira burhandan ortaya çıan, zorunlu, mümkün

${ }^{5}$ Nasîrüddin Tûsî, şerhu'l-işââât (el-işsârât ve't-tenbîhât içerisinde), thk. Kerim Feyzî (Kum: Matbuat-i Dinî, 1383).

6 Şemsüddîn Semerkandî, Kıstâsu'l-Efkâr-Düşüncenin Kıstast-, çev. Necmettin Pehlivan (İstanbul: Türkiye Yazma Eserler Kurumu Başkanlığı, 2014).

7 bk. M. Naci Bolay, "Beş Sanat", Türkiye Diyanet Vakfi İslâm Ansiklopedisi (İstanbul: TDV Yayınları, 1992), 5/546-547.

8 Şemsüddîn Semerkandî, Beşârâtü'l-işârât, thk. Ali Ucabî (Tahran: Miras-1 Mektûb, 2021), 1/240; Semerkandî, Kıstâsu'l-Efkâr, 476.

9 Tûsî, Şerhu'l-İşârât, 1/387.

${ }^{10}$ Burhan, yakîn ifade eden evveliyât, müşâhedât, mücerrebât, hadsiyât, mütevâtirât ve kıyasları beraberinde olan önermelerden meydana gelen kıyastır. Bk. Ali b. Ömer Kâtibî, eş-Şemsiyye fi Kavâidi'l-mantıkiyye, thk. Mehdî Fazlullâh (Beyrut: el-Merkezü's-sekâfi'l-'Arabî, 1998), 231; Esirüddin Ebherî, Îsâgûcî-Mantığa Giriş-, çev. Hüseyin Sarıoğlu (Ankara: Türkiye Bilimler Aka- 
veya vücudî olabilir. ${ }^{11} \mathrm{Bu}$ durumda burhan, sadece kıyas olmaktadır. Diğer akıl yürütme çeşitleri olan tümevarım (istikra) ve analoji (temsil), yakinî sonuç vermediklerinden burhan içerisinde değerlendirilmez. ${ }^{12}$ Kısaca ifade edecek olursak burhanî kıyaslar; maddesi ve sureti yakinî öncüllerden oluşan ve yakinî sonuç veren kıyaslardır. ${ }^{13}$

Beş sanatın diğer bir sınıfı olan cedelî (diyalektik) kıyaslar, meşhur ve takrîriyyat öncüllerinden yapılan kıyastır. ${ }^{14}$ Bu tür kıyasların kipleri, vacib, mümkün veya mümtenî olabilir. Cedelî kıyasların amacı hasmı ilzam ya da ilzamı def etmektir.

Beş sanat içerisinde incelenen hatabî (retorik) kıyaslar, ister hak ister batıl olsun, maznûnât ve makbulâttan ve de meşhur olanlara benzeyen öncüllerden meydana gelen kıyastır. ${ }^{15}$ Cedelî kıyaslarda olduğu gibi hatabî kıyasların suretlerinin de kıyas, tümevarım ve analoji gibi zânn-1 gâlib bakımından sonuç vermesi mümkündür. Zira hatabî kıyasların amacı iknâdır.

Söz konusu şiirî kıyaslar ise -doğru ya da yanlış olsun- hayale dayalı öncüllerden meydana gelen kıyaslardır. ${ }^{16}$ Kısaca şiirî kıyaslar, doğruluktan dolayı, nefsin etkilendiği bir yapı (hey'et) ve telif özelliği bulunan öncüllerden meydana gelen kıyaslardır. ${ }^{17}$ İbn Sînâ'ya göre şiirî kıyasların öncüllerinin doğru olmasında bir problem yoktur. Ayrıca vezin de onları revaçta tutar. ${ }^{18}$

Semerkandî, benzeyen öncüllerden (müşebbihât) meydana gelen k1yasları iki kısımda ele almaktadır. Söz konusu kabulü zorunlu olanlara benzeyen öncüllerden meydana gelen klyaslara "safsata" denir. Safsata kıyası yapana "sofist" denir. Semerkandî, yanıltma yoluyla (tağlit) bilip bilmediğini imtihan yapmak için yapılan muğâlatalı kıyasların, sofistik kıyasların altında yer aldığını ifade ederek, İbn Sînâ ile aynı görüşte oldu-

demisi, 2016), 91; Ferruh Özpilavc1, Kâtibî Şemsiyye Risâlesi-Tahkik, Çeviri ve Şerh- (İstanbul: Litera Yayıncilik, 2017), 417-419.

${ }^{11}$ Semerkandî, Beşââatü'l-Ișârât, 1/240.

${ }^{12}$ Kutbuddin Râzî, el-Muhâkemât beyne şerhayi'l-İşââat ve't-tenbîhât (el-isşârât ve't-tenbîhât içerisinde) (Kum: Matbuat-i Dinî, 1383), 1/386.

${ }^{13}$ Tûsî, Șerhu'l-İșârât, 1/387.

${ }^{14}$ Cedelî kıyaslara “Zulüm kötüdür ve adalet güzeldir." öncüllerini örnek verebiliriz. Bk. Kâtibî, eş-Şemsiyye, 231; Özpilavc1, Kâtibî Şemsiyye Risâlesi, 424-425.

${ }^{15}$ Hatabî kıyaslara "Filan kişi, geceleyin etrafta dolaşıyor. O halde hırsızdır." öncüllerini örnek verebiliriz. Bk. Kâtibî, eş-Şemsiyye, 232.

${ }^{16}$ Şiirî kıyaslara "Şarap, akışkan yakuttur ve bal, kusturucu acıdır." öncüllerini örnek verebiliriz. Bk. Kâtibî, eş-Şemsiyye, 232; Özpilavcı, Kâtibî Şemsiyye Risâlesi, 429.

${ }^{17}$ Semerkandî, Beșârâtü'l-İsârât, $1 / 240$.

${ }^{18}$ Ebu Ali İbn Sînâ, İşaretler ve Tembihler, çev. Ali Durusoy vd. (İstanbul: Litera Yayıncılık, 2013), 70. 
ğunu ifade eder. ${ }^{19}$ Eğer kıyas meşhûrâta benzeyen öncüllerden meydana gelirse "müşağabe" adını alır. Müşağabeli kıyası kullanana "müşâğibı̂" denir. Müşâ̆gibî, cedelcinin karşısında yer alırken; sofist de filozofun (hakîmin) karşısında yer alır. Semerkandî, müşağabenin cedele, safsatanın da burhana benzerliğinden dolayı İbn Sînâ'nın bu şekilde bir sınıflandırma yoluna gittiğini söyler. ${ }^{20}$

\subsection{Bilimsel Sorular ve Kiyaslar}

İbn Sînâ bilimsel soruları (metâlib), ilk taksimde üçe; ikinci taksimde de altı kısma ayırır. Birinci taksimde bilimsel sorular, "nedir?", "mi?" ve "niçin?" sorularından oluşmaktadır. ${ }^{21}$ Tûsî, Şerhu'l-Iş̧ârât adlı eserinde bilimsel soruları, asıllar ve furû' olarak ikiye ayırır. Asılların tümel olduğunu bu soruların "ana sorular" olarak isimlendirildiğini belirterek, bilkuvve bu soruların altı olduğunun söylenebileceğini belirtir. Furû' olan soruların ise tikel olduğunu belirtir. Tûsîye göre bu asıllara "hangisi?" sorusu eklendiğinde, "nedir?" ve "hangisi?" soruları ile tasavvur talep edilirken; "mi?" ve "niçin?" soruları ile de tasdik talep edilmektedir. ${ }^{22}$

Semerkandî, Tûsî'de olduğu gibi bilimsel soruları asıl ve furû' olarak iki kısımda ele alır. O, Kıstâsu'l-Efkâr ve Beşârâtü'l-İşârât adlı eserlerinde ana soruları "nedir?", "mi?", "niçin?" ve "hangisi?" olarak dört kısımda inceler. ${ }^{23}$ Semerkandî, mezkûr eserlerinde İbn Sînâ'dan farklı olarak ana soruları dört kısımda ele almaktadır. İbn Sînâ, II. Analitikler adlı eserinde ana soruları üç kısımda ele almaktadır. Ancak "hangi" sorusunu, diğer sorulardan ayrı bir konuma koyar. İbn Sînâ'ya göre "hangi" sorusu daha basittir ve talep edilen şeye daha güçlü bir delalete sahiptir. Zira "hangi" sorusu ile bir şeyi ona özgü niteliklerle ayrıştırmak talep edilmektedir. ${ }^{24}$

Bilimsel ana sorulardan olan "mi?" sorusu, basit ve bileşik olarak ikiye ayrılır. Basit olan "mi?" sorusu ile mutlak olarak bir şeyin var olup olmadığı talep edilir. Mesela, “Zeyd mevcut mudur?" sorusu ile Zeyd'in mutlak olarak var olup olmadığ talep edilmektedir. Semerkandî’ye göre bileşik olan "mi?" sorusu ile var olan şeyin içerisinde bulunduğu hal talep edilir. Mesela, "Zeyd odanın içerisinde midir?" sorusu ile Zeyd'in mevcut olduğu hal talep edilmektedir. Söz konusu talep eden, ister basit ister bileşik

${ }^{19}$ Semerkandî, Beşââatü'l-işârât, 1/241; krş. İbn Sînâ, İşaretler ve Tembihler, 71.

${ }^{20}$ Semerkandî, Beşârâtü'l-İşârât, 1/241; krş. İbn Sînâ, İşaretler ve Tembihler, 71; ayrıca bk. Ferruh Özpilavcı, Kâtibî Şemsiyye Risâlesi-Tahkik, Çeviri ve Şerh- (İstanbul: Litera Yayınc1lık, 2017), 432433.

${ }^{21}$ Ebu Ali İbn Sînâ, íkinci Analitikler, çev. Ömer Türker (İstanbul: Litera Yayıncllı, 2015), 18.

${ }^{22}$ Tûsî, şerhư'l-İşârât, 1/409.

${ }^{23}$ Semerkandî, Beşârâtü'l-Ișââât, 1/256; Semerkandî, Kıstâsu'l-Efkâr, 496.

${ }^{24}$ bk. İbn Sînâ, Íkinci Analitikler, 18-19. 
olsun "mi?" soru edatı ile var olan veya var olmayan iki durumdan birini bilmek ister. ${ }^{25}$

Bilimsel ana soruların ikincisi "nedir?" sorusudur. Söz konusu "nedir?" sorusu ile iki şey talep edilir. Birincisinde var olan şeyin zatının mahiyeti talep edilir. İkincisinde ise onunla kullanılan ismin mefhumunun mahiyeti talep edilir. Mesela, "Insan nedir?" diye sorulduğunda burada talep edilen insanın mahiyeti olduğundan burada bir bilgi elde edilir. Var olan şeyin zatının mahiyeti de had ve resm/betim ile elde edilir. Söz gelimi "Boşluk nedir?" diye bir soru sorulduğunda "boşluk" isminin mefhumunun mahiyeti bilinmek istenmektedir. Semerkandî'ye göre bu şekilde ismin icmâlen delalet ettiği şey ayrıntılandırılarak cevap verilmektedir. Birincisi hakikat; ikincisi ise isim bakımından tanımdır. ${ }^{26}$

Bilimsel ana soruların üçüncüsü "hangi?" sorusudur. "Hangi?" sorusu ile ya şey olma (şey'iyyet) manasında ya da daha özel bir ortaklık durumu bilindikten sonra birbirinden ayırt edilmesi istenir. Bu ayırt edilme "o hangi şeydir?" sorusu ile mümkün olmaktadır. Dolayısıyla "hangisi?" sorusu ile şeyin kendi dışındaki zâtilerinden, avarızlardan ayırt edilmiş olur. Semerkandî, "nedir?" sorusunun "hangi?" sorusuna ihtiyaç duymadığından dolayı onun furû' olanlardan olduğuna dair bir görüş dile getirir. ${ }^{27}$

Bilimsel ana soruların sonuncusu "niçin?" sorusudur. Semerkandî, İbn Sînâda ${ }^{28}$ olduğu gibi "niçin" sorusunu iki kısımda ele alır. Birinci durumda sadece "var mıdır?" sorusunun cevabıyla tasdikin meydana gelmesi amaçlandığında, "niçin" sorusu ile orta terim talep edilir. İkinci durumda ise sadece tasdikin meydana gelmesi amaçlanmadığında, bu durumda büyük terimin küçük terime nisbetinin sebebi talep edilmektedir. Birinci duruma burhan-1 innîdeki orta terim cevap olurken; ikinci duruma ise burhan-1 limmideki orta terim cevap olur. ${ }^{29}$ Kisaca ifade edecek olursak "niçin" sorusu ile mutlak olarak hüküm ya da hükmün sabit oluşu talep edilir.

Semerkandî, ana soruları ele aldıktan sonra furû' olarak ifade ettiği ikincil soruları ele almaktadır. Ana sorularda olduğu gibi bu soruları da İbn Sînâ'yı takip ederek inceler. "Bu şey nasıldır?" "bu şey nerededir?", "bu şey ne zamandır?" "kaç?" ve "ne zaman?" söz konusu sorulardandır. $\mathrm{Bu}$ ifade edilen sorular, ana sorulara kıyasla tikel sorulardır. İkincil soru-

${ }^{25}$ Semerkandî, Beşârâtü'l-Işârât, 1/256; krş. Ebu Ali İbn Sînâ, İşaretler ve Tembihler, çev. Ali Durusoy vd. (İstanbul: Litera Yayıncilik, 2013), 74.

${ }^{26}$ Semerkandî, Beşârâtü'l-Ișârât, 1/256; Semerkandî, Kıstâsu'l-Efkâr, 496; krş. Tûsî, Şerhu'l-ișârât, $1 / 409$.

${ }^{27}$ Semerkandî, Beşârâtü'l-İ̧sârât, 1/257; Semerkandî, Kıstâsu'l-Efkâr, 498.

${ }^{28}$ bk. İ̉n Sînâ, İsaretler ve Tembihler, 74; İbn Sînâ, íkinci Analitikler, 18.

${ }^{29}$ Semerkandî, Beşââatü'l-Ișârât, 1/258. 
lar, birincil sorular kadar kapsayıcı bir faydaya sahip değillerdir. Niteliği olmayan bir şey hakkında "nasıl?" sorusu sorulmadığı gibi herhangi bir yerde bulunmayan bir şey hakkında "nerede?" sorusu sorulmaz. Bu durum diğerleri için de geçerlidir.

\subsection{Bilimlerin İlkeleri ve Konuları}

Her bilimin kendisine özgü konusu, ilkeleri ve meseleleri vardır. Her bilim için araştırdığımız, birbirleriyle uyumlu bir şey veya şeyler vardır. İşte bu şeylere zâtî arazlar denir. Söz konusu bu şey veya şeylere "konu" denir. Mesela, insan bedeni, organlar, ilaçlar ve gıdalar tıp ilminin konusu olurken; miktar ve sayı ise geometri ve matematik ilminin konusu olmaktadır. Zira mühendis, matematikçi ve doktor bu bilimlerdeki zâtî arazları incelemektedir. Dolayısıyla bu şeylerin bilimlerin konusu olduğu ifade edilir. Çünkü bu bilimin meselelerinin konuları, onlara, onların türlerine veya onların zâtî arazlarına bağlıdı.. ${ }^{30}$

İslâm felsefesinin ontoloji ve epistemoloji disiplinlerinde sıkça kullanılan mebde için Türkçe'de ilke kavramı kullanılır. Grekçe'de arkhe ve Latince'de principium kavramları ilke için türetilmiştir. ${ }^{31}$ İbn Sînâ'ya göre bir bilimin ilkeleri; tanımlar ve kendisinden kıyas yapılan öncüllerden meydana gelmektedir. ${ }^{32}$ Semerkandî, bilimin ilkeleri konusunda İbn Sînâ'nın ifadelerini açılama yoluna giderek, konunun anlaşılmasına katkı sağlamaktadır. Semerkandî̀ye göre ilkeler, bir bilimin araştırmalarının kendi üzerine bina edildiği şeylerdir. Semerkandî, Tûsî'de olduğu gibi ilkeleri tasavvurlar ve tasdikler olarak inceler. Söz konusu tasavvurlar; bilimin konusunun parçalarının, daha tâlî kısımlarının ve zata ilişen arazlarının tanımlarından meydana gelir. Tasdikler ise kendilerinden o bilimin kıyaslarının oluşturulduğu veya kendilerine ulaşılan öncüllerden meydana gelir. Bu öncüller kabulü zorunlu olan ve kabulü zorunlu olmayan olarak ikiye ayrılır. Kabulü zorunlu olanlar, ya evveliyât gibi genel olur ki bunlar "müteârife" olarak isimlendirilir. Mesela, bir şeyin, aynı anda iki yerde bulunmaması, kabulü zorunlu olan geneldir. Kabulü zorunlu olanlar bir ya da birkaç ilme özgü olur. Mesela, "bir şeye eşit nicelikler bir birine eşittir." önermesi bu duruma örnektir. Zira bu önerme geometri ve matematik ilmine özgüdür. Kabulü zorunlu olmayanlar ise "usûlü mevdûa" ve "musâderât" olarak ikiye ayrılır. Usûlü mevdûa, öğ-

30 Semerkandî, Beșârâtü'l-İşârât, 1/246; Semerkandî, Kıstâsu'l-Efkâr, 488.

31 İlhan Kutluer, "Mebde", Türkiye Diyanet Vakfı İslâm Ansiklopedisi (Ankara: TDV Yayınları, 2003), 28/210; Seyyid Şerif Cürcânî, Tarîfât: Arapça-Türkçe Terimler Sözlüğü, çev. Arif Erkan (İstanbul: Bahar Yayınları, 1997), 200.

32 İbn Sînâ, İşaretler ve Tembihler, 72. 
rencinin zan yoluyla kabul etmesidir. Musâderât ise öğrencinin nefsinde bir şüphe bulunduğu halde açıklanacağı zamana kadar doğruluğu kabul edilendir. ${ }^{33}$ Semerkandî'ye göre bazen evvelî önermeler ve tanımlar "vaz' (konu)" isminde toplanırlar. Bu durumda bunlara "vazlar (evda')" denir. Bu tür önermeler, herhangi bir ilim dalında hiçbir şekilde açıklığa kavuşturulamayabilir ya da ilgili olduğu bilim veya başka bir bilimden burhan getirilerek açıklanır. ${ }^{34}$

Meselelere gelince, bilimin içerdiği ve bilimde kendisi hakkında delil istenen önermelerdir. Semerkandî, meselelerin konularının ve yüklemlerinin olduğunu belirtir. Söz konusu meselelerin konuları daha önce geçtiği üzere bilimin konusu, türleri ve zâtî arazlarından oluşmaktadır. ${ }^{35}$ Meselelerin yüklemlerinin ise konuları için kurucu bir unsur olmaması gerekir. Zira kurucu unsur burhansız bilinir. ${ }^{36}$ Semerkandî, konunun bazı yönlerden tasavvur edilmesi durumunda delille bilinen bir şey olabileceği kanaatindedir. ${ }^{37}$

\subsection{Burhan ve Bilimler Arası İlişkiler}

Semerkandî, bilimleri konuları bakımından sınıflandırmaya tabi tutmaktadır. Söz konusu bilimleri konuları bakımından "mütedâhil", "mütenâsib" ve "mütebâyin" olarak üç kısımda inceler. Semerkandî’ye göre bilimlerin konuları, bazı bilimlerin konularından daha gene olursa "mütedâhil" olarak isimlendirilir. Bu genellik, cins olur ya da konu bu bilimlerin birinde mutlak olarak alınmışken diğerinde ise özel bir durumla kayıtlanmış olur. Semerkandî, konusu özel olan bilimin, "konusu daha genel olanın altında yer alan” olarak isimlendirildiğini ifade eder.

Genelliği cins olana geometrik cisimleri ve geometri bilimini örnek olarak verebiliriz. Çünkü geometrik cisimler biliminin konusu, geometri biliminin konusunun altında yer alır. Söz konusu geometrik cisimler biliminin konusu "ta'lîmî cisimler" iken; geometri biliminin konusu ise "miktar" olmaktadır. Dolayısıyla miktar, ta'lîmî cismin cinsi olmaktadır. Semerkandî, konusu mutlak ve mukayyed olanlara İbn Sînâ'da olduğu gibi hareketli küreler ve küreler bilimini örnek olarak verir. Söz konusu hareketli küreler bilimi, küreler biliminin altında yer almaktadır. Yukarıda ifade ettiğimiz iki tarz, tek bir konuda birleşebilir. Bu durumda "konu"

${ }^{33}$ Benzer ifadeler için bk. Kutbuddin Râzî, Tahrîrü'l-kavâidi'l-mantıkiyye fi şerhi'r-Risâleti'ş-Şemsiyye (el-Risâletü'ş-Şemsiyye içinde), thk. Muhsin Bîdârfer (Kum: Menşûrât-1 Bîdâr, 1426), 469.

${ }^{34}$ Semerkandî, Beșârâtü'l-İșârât, 1/247-248; Semerkandî, Kıstâsu'l-Efkâr, 488-489; krş. Tûsî, Șerhư'lișârât, 1/399-401.

${ }^{35}$ Semerkandî, Beşââatü'l-ișârât, 1/248.

${ }^{36}$ Semerkandî, Kıstâsu'l-Efkâr, 490.

${ }^{37}$ Semerkandî, Beşââatü'l-ișârât, 1/248. 
ismine daha uygun olan özel bilim olur. Mesela, optik bilimini örnek verebiliriz. Zira optik biliminin konusu, iki yönden geometri biliminin konusundan daha özeldir. ${ }^{38}$

Bazen herhangi bir bilimin konusu, başka bir bilimin konusundan ayrı olur. Fakat âraz olması bakımından iki bilimden birinin konusu, diğerine özgü olması açısından incelenir. Bu kısma mûsiki ve matematik bilimini örnek verebiliriz. Zira mûsikinin konusu, terkib yönünden sayısal nisbetlerin kendisine ilişmesi bakımından "nağme" olur. Sayısal nisbet ise konusu sayı olan matematik ilmine özgü arazdır. Görüldüğü üzere mûsiki ve matematik, konuları bakımından ayrı olmalarına rağmen mûsiki bilimi, matematiğin altında kabul edilmektedir. Çünkü nağmelerde sayısal nisbetler araştırıldığında, kaçınılmaz olarak sayılarında araştııılması zorunlu olur. Dolayısıyla matematiğin konusu olan sayıların altında yer almaktadır. ${ }^{39}$

Semerkandî, bazı bilimlerin birbirlerine nisbeti tek olduğunda, tek bir şeyin iki bilimin konusu olması durumunda "mütenâsib"; böyle olmadığında ise "mütebâyin" olarak isimlendirildiğini belirtir. Mesela, âlemdeki cisimlerin şekilleri bakımından hey'et biliminin; tabiatları bakımından tabiî bilimlerden olan semâ ve âlemin konusu olması gibi mütenâsib olurlar. ${ }^{40}$ Dolayısıyla bazı meseleler, burhanları bakımından farklılık göstermesine rağmen birleşebilirler. Mesela, dünyanın yuvarlak olması ve semânın ortada olmasında durum böyledir. Birincisinin burhanı "innî", diğerinin ise "limmî" olur. ${ }^{41}$

Semerkandî, tıp ve ahlak ilminde olduğu gibi bazen bilimlerin konularının ayrı; ancak araştırmada ortak olabileceğini ifade eder. Tip ilminin konusu, sağlık ve hastalık bakımından insan bedeni olurken; ahlakın konusu ise kendisinden fiillerin ortaya çıkması bakımından insan beni olmaktadır. Görüldüğü üzere tıp ve ahlakın konuları birbirinden ayrıdır. Ancak konu bakımından farklı olmalarına rağmen söz konusu bilimler, insanın kuvvelerini incelemeleri noktasında ortaktırlar. Bazen de bilimlerin konuları ayrı olur; ancak tek bir cinsin altında yer alabilirler. Mesela, geometri biliminin konusu miktar, matematiğin ise sayıdır. Bu iki bilimin konusu farklı olmasına rağmen, nicelik kategorisinin altında kabul edilmektedirler. Semerkandî son olarak konuları mütebâyin olan bilimlere, fizik (tabiî) ve matematik bilimlerini örnek verir. Zira fizik biliminin ko-

38 Semerkandî, Beşârâtü'l-İşârât, 1/249; krş. İbn Sînâ, İşaretler ve Tembihler, 73; bk. Semerkandî, Kistâsu'l-Efkâr, 490.

39 Semerkandî, Beşârâtü'l-İşârât, 1/250; bk. Semerkandî, Kıstâsu'l-Efkâr, 490.

40 Semerkandî, Beșârâtü'l-İşârât, 1/250.

${ }^{41}$ Semerkandî, Kıstâsu'l-Efkâr, 492. 
nusu hareket ve sükûn bakımından cisim iken; matematiğin konusu ise sayıdır. ${ }^{42}$ Özetle Semerkandî̀nin, konuları bakımından sınıflandırmasında genel olarak İbn Sînâ'yı takip ettiğini söyleyebiliriz. İbn Sînâ’nın özet olarak incelediği konuyu, Semerkandî, örneklerle zenginleştirerek daha belirgin bir hale getirmiştir.

Semerkandî, alttaki ilmi, üstteki ilme klyasla "tikel"; üstteki ilmi de alttaki ilme kıyasla "tümel" olarak isimlendirilmektedir. Konusu tikel olan bilimdeki usûl-ü mevdûanın çoğu, tümel ilmin açıklamalarına ihtiyaç duyar ve tümel ilimde açıklı̆̆a kavuşur. Mesela, "cismin heyûlâ ve sûretten oluşması" ve "dört illet" de durum böyledir. Çünkü ikisi, tabiatın ilkeleri ve İlk Felsefenin problemlerindendir. Semerkandî, tümel ilimdeki usûl-ü mevdûanın çoğunun tikel ilminin açıklamalarına ihtiyaç duyabileceğini belirtir. Mesela, cismin parçalanmayan parçalardan oluşmasının imkânsızlığında olduğu gibi tabiat ilminin meselelerinden ve İlk Felsefenin ilkelerinden olmaktadır. Semerkandî, kısır döngüyü (devr) gerektirmeyen bir yönden olmasını şart koşar. ${ }^{43}$

Semerkandî, özel ve genel olması yönünden bilimlerin konusunun, daha genel olanda son bulacak şekilde düzenlenebileceği kanaatindedir. Bu kanaatini destekleyecek tarzda İlk Felsefe ve tıp bilimlerini örnek vermektedir. Zira İlk Felsefeden daha özeli fizik (tabiî) bilim, ondan da daha özeli tıp bilimidir. Çünkü İlk Felsefede vahdet-kesret, zorunlu-mümkün, kadîm-hadîs, sebep (illet)-sebepli (ma'lûl), basit-bileşik ve bunların dışındakiler gibi varlığın zâtî arazları incelenir. ${ }^{44}$

Son olarak Semerkandî, burhanın nakli konusunu inceler. Semerkandî̀ye göre burhanın, bir bilimden diğerine nakli iki şekilde yapilabilir. (1) Bir bilimde mesela olan usûlü mevdûanın başka bir bilimde burhan ile açıklanması ve ondan kabul edilip alınması ile nakli yapılır. Mesela, tabiat ilminde, ilk Felsefe'de zikredilen burhanla cisimlerin heyûlâ ve sûretten oluştuğunu açıklamayı örnek verebiliriz. (2) Burhan, genel bir bilimden özel bir bilime nakledilir. Mesela, geometrik burhanları optik ilminin meselelerine, matematiğin burhanlarını da mûsîkinin meselelerine nakletmeyi örnek olarak verebiliriz. ${ }^{45}$

\subsubsection{Burhanın Çeşitleri}

Orta terim, hükmün tasdikinin illeti olması gerekir. Söz konusu orta

${ }^{42}$ Semerkandî, Beşârâtü'l-İşâât, 1/250.

${ }^{43}$ Semerkandî, Beșârâtü'l-İșârât, $1 / 251$.

${ }^{44}$ Semerkandî, Beşârâtü'l-Işââât, 1/251; ayrıca bk. Semerkandî, Kıstâsu'l-Efkâr, 490.

${ }^{45}$ Semerkandî, Beşârâtü'l-Işârât, 1/251; benzer ifadeler için bk. Semerkandî, Kıstâsu'l-Efkâr, 492493. 
terim, yüklemleme, lüzum, inâd ve bunların olumsuzlanması şeklinde nefsü'l-emrde büyük terimin küçük terime nisbetinin nedeni olursa "burhan-1 lime (nedensellik burhanı)" olarak isimlendirilir. Zira burhan-1 lime, nefsü'l-emrde hem tasdikin hem de hükmün sebebini vermektedir. Semerkandî, bu durumda burhan-1 limenin ayanda ve zihinde mutlak olarak illeti verdiğini belirtir. Orta terim sadece yalnızca tasdikin illetin olursa "burhan-1 innî(varlık burhanı)" olarak isimlendirilir. Zira burhan-1 innî hükmün inniyetine delalet eder. Yani hükmün limmiyetine değil kendindeki sabit oluşuna işaret eder.

Semerkandî, burhan-1 innede orta terimin, büyük terimin küçük terime nisbeti dolayısıyla ma'lûl (nedenli) olabileceğini ifade ederek İbn Sînâ ile aynı görüşü paylaşmaktadır. Söz konusu büyük terim ve küçük terim bazen tek bir illetin ma'lûlü olabilir. Eğer orta terim ma'lûl olursa ve illetten daha çok bilinirse bu durumda "delil" olarak isimlendirilir. Mesela, "Eğer ay tutulmuş ise öyleyse yeryüzü güneş ile ayın ortasındadır. Fakat ay tutulmuştur; o halde yeryüzü ortada olandır." Semerkandî̀nin vermiş olduğu bu örnek bitişik şartlı kıyaslar içindir. İstisnâî kıyaslardaki istisna, iktirânî kıyaslardaki orta terim gibidir. Zira ortada olma, ortada olmanın ma'lûlü olan tutulma ile açıklanmıştır. Söz konusu olan tutulma; yeryüzünün ortada olmasıyla açıklanırsa bu durumda burhan-1 limmî olur. Mesela, "Eğer yeryüzü güneş ile ayın ortasındaysa ay tutulmuştur. Fakat ay tutulmuştur; o halde ay tutulmuştur."

Semerkandî, İbn Sînâ'da olduğu gibi ortak terimlerle iki yönden yüklemli bir kıyas yapılacağını mümkün görmektedir. Bu yönlerin birincisini burhan-1 limmî diğerini ise burhan-1 innî oluşturmaktadır. Mesela, burada küçük terim sıtmaya tutulma; büyük terim ve orta terim sitma nöbetinden ve içerideki bir yaradan dolayı titreme olduğunda, bu ikisinin ma'lûlü titreme olur. "Bu adam sitma nöbetinden dolayı titremektedir. Çünkü onun içerisinde yara vardır." dediğimiz örnek burhan-1 limmî için olur. Söz konusu örneği değiştirerek "Bu adamın içinde yara vardır. Çünkü o sıtma nöbetinden dolayı titremektedir." şeklini aldığında örnek burhan-1 innî için olur. ${ }^{46}$

Semerkandî, burhan-1 limmîde orta terimin dört nedenin her birinde meydana geleceğini ifade eder. Söz konusu dört illet; fâil, maddî, sûrî ve gâ̂i illetten oluşur. Fail illet yüklemli, lüzûmiyye ve ayrık şartlı olur. Mesela, "Yeryüzü, iki ışık arasında olursa, ay tutulur. Fakat ay, iki ışık arasındadır. O halde ay tutulmuştur." Maddî illete gelince "Beden farklı parçalardan oluşan cisimdir. Çünkü o, unsurlardandır." örneğini verebiliriz. Sûrî

${ }^{46}$ Semerkandî, Beşârâtü'l-İşârât, 1/253; bk. İbn Sînâ, İşaretler ve Tembihler, 73-74. 
illete ise "Su basittir. Çünkü o, kürevidir." örneğini verebiliriz. Son olarak gâî illete ise "Değirmenler geniştir. Çünkü onlar, iyice öğütmek içindir." örneğini verebiliriz. Semerkandî, bu kısımlardaki orta terimin büyük terime dönüştürüldüğünde burhanın, burhan-ı innî olacağını belirtir. Zira orada dört nedenin her birinde orta terim bulunur. ${ }^{47}$

\section{Sonuç}

13. yüzyılda yaşayan ve yaşadı̆̆ı dönemin ilim geleneğine uygun eserler vermiş olan Şemsüddin Semerkandî, daha çok mantık, kelam ve felsefe alanlarında yazdığı eserlerle bilinmektedir. Hayatı hakkında bilgiler sinırlıdır. 722/1322 yılında vefat etmiştir. Felsefe ve mantık alanında yazdığı önemli eserlerden biri de Beşârâtü'l-İşârât'tır. Bu eser İbn Sînâ'nın el-İşârât'1 üzerine yazılan önemli şerhlerden biridir. Semerkandî, bu şerhinde genel olarak İbn Sînâ'nın görüşlerini açıklama yoluna gitmektedir.

Semerkandî, burhani ilimler konusunda ilk olarak maddesi bakımından kıyasları inceleríbn Sînâ'nın özet olarak ele aldı̆̆ı konuyu detayland1rarak konunun daha anlaşılır olmasını sağlar. Şöyle ki maddesi bakımından kıyas beş sınıfa ayrılır. Söz konusu bu beş sınıfa beş sanat denir. Beş sanat; burhan, cedel, hitabet, şiir ve muğalatadan meydana gelir. Bilimsel sorular konusunda ise İbn Sînâ'dan farklı bir şekilde Tûsînin şerhinde olduğu gibi soruları "asıl" ve "furû"” olarak ikiye ayırır. Bu konuda dikkat çekici husus "hangi?" sorusunun asıl mı yoksa furû içerisinde mi olduğuna dair tartışmadır. İbn Sînâ'ya göre "hangi" sorusu daha basittir ve talep edilen şeye daha güçlü bir delalete sahiptir. Zira "hangi" sorusu ile bir şeyi ona özgü niteliklerle ayrıştırmak talep edilmektedir. Semerkandî ise "nedir?" sorusunun "hangi?" sorusuna ihtiyaç duymadığından dolayı onun furû’ olanlardan olduğuna dair bir görüşü dile getirir.

Semerkandî, bilimlerin ilkeler konusunda İbn Sînâ'da olduğu gibi konu, ilke ve meseleleri ele alır. İbn Sînâ'nın bu konudaki görüşlerini ele alarak konunun daha ayrıntılandırıldı̆̆ını görmekteyiz. Semerkandî, Tûsî'de olduğu gibi ilkeleri tasavvurlar ve tasdikler olarak inceler. Söz konusu tasavvurlar; bilimin konusunun parçalarının, daha tâlî kısımlarının ve zata ilişen arazlarının tanımlarından meydana gelir. Tasdikler ise kendilerinden o bilimin kıyaslarının oluşturulduğu veya kendilerine ulaşılan öncüllerden meydana gelir. Semerkandî, bilimler arasındaki ilişkiye de değinir. İbn Sînâ'dan farklı olarak "mütenâsib”, "mütebâyin" ve mütedâhil” kavramlarını ele alarak, örneklerle konunun anlaşılmasını sağlar. Semerkandî'nin bu konudaki açıklamaları Kıstâsu'l-Efkâr adlı ese-

${ }^{47}$ Semerkandî, Beşârâtü'l-İşârât, 1/255. 
rindeki açıklamalarıyla benzerlik gösterir. Söz konusu bilimlerin konuları, bazı bilimlerin konularından daha genel olursa "mütedâhil" bazı bilimlerin birbirlerine nisbeti tek olduğunda, tek bir şeyin iki bilimin konusu olması durumunda "mütenâsib"; böyle olmadığında ise "mütebâyin" olarak isimlendirilir. Semerkandî, son olarak burhanın çeşitlerini ele alarak şerhteki konuyu bitirir. Söz konusu orta terim, yüklemleme, lüzum, inâd ve bunların olumsuzlanması şeklinde nefsü'l-emrde büyük terimin küçük terime nisbetinin nedeni olursa "burhan-1 limmî (nedensellik burhanı)" olarak isimlendirilir. Orta terim sadece yalnızca tasdikin illetin olursa "burhan-1 innî (varlık burhanı)" olarak isimlendirilir.

Semerkandî̀nin şerhi Fahreddin Râzî ve Tûsînnin şerhlerinden daha sonra yazıldığı için mezkûr iki şerh kadar meşhur olmamıştır. Ancak şu var ki bu şerh felsefe-mantık alanında önemli eserlerden biridir. Söz konusu şerh İbn Sînâ'nın eserdeki yöntemini bize sunmasının yanında Semerkandî’nin görüşlerini içermesi açısından önemli bir kitaptır. Son olarak Semerkandî̀nin kaynakları arasında başta İbn Sînâ’nın eş-Şifâ külliyatı olmak üzere Fahreddin Râzî ve Tûsînnin şerhlerini sayabiliriz. Kendisi Kıstâsu'l-Efkâr eserinden de fazlasıyla yararlanmaktadır.

\section{Kaynakça}

Baga, Mehmet Sami. "el-İşârât “in "Garip” Bir Şerhinin Müellifi: Şemsüddin Semerkandî ve Beşârâtü'l-işârât Adlı Eseri”. Bingöl Üniversitesi İlahiyat Fakültesi Dergisi 3/5 (2015), 221-246.

Bolay, M. Naci. "Beş Sanat”. Türkiye Diyanet Vakfi İslâm Ansiklopedisi. 5/546-547. İstanbul: TDV Yayınları, 1992.

Cürcânî, Seyyid Şerif. Tarîfât: Arapça-Türkçe Terimler Sözlüğü. çev. Arif Erkan. İstanbul: Bahar Yayınları, 1997.

Ebherî, Esirüddin. Îsâgûcî-Mantığa Giriş-. çev. Hüseyin Sarıŏlu. Ankara: Türkiye Bilimler Akademisi, 2. Basım, 2016.

İbn Sînâ, Ebu Ali. İkinci Analitikler. çev. Ömer Türker. İstanbul: Litera Yayıncılık, 2015.

İbn Sînâ, Ebu Ali. İşaretler ve Tembihler. çev. Ali Durusoy vd. İstanbul: Litera Yayıncllik, 2013.

Kâtibî, Ali b. Ömer. eş-Şemsiyye fî Kavâidi'l-mantıkiyye. thk. Mehdî Fazlullâh. Beyrut: el-Merkezü's-sekâfi'l-'Arabî, 1998.

Kutbuddin Râzî. el-Muhâkemât beyne şerhayi'l-Işsârât ve't-tenbîhât (el-İşârât ve'ttenbîhât içerisinde). 3 Cilt. Kum: Matbuat-i Dinî, 1383.

Kutbuddin Râzî. Tahrîrü'l-kavâidi'l-mantıkiyye fî Şerhi'r-Risâleti'ş-Şemsiyye (elRisâletü'ş-Şemsiyye içinde). thk. Muhsin Bîdârfer. Kum: Menşûrât-1 Bîdâr, 3. Basim, 1426. 
Kutluer, İlhan. "Mebde". Türkiye Diyanet Vakfi İslâm Ansiklopedisi. 28/210-211. Ankara: TDV Yayınları, 2003.

Kutluer, İlhan. "Muhammed b. Eşref es-Semerkandî”. Türkiye Diyanet Vakfi İslâm Ansiklopedisi. 36/475-477. İstanbul: TDV Yayınları, 2019.

Özpilavc1, Ferruh. Kâtibî Şemsiyye Risâlesi-Tahkik, Çeviri ve Şerh-. İstanbul: Litera Yayıncilık, 2017.

Semerkandî, Şemsüddîn. Beşârâtü'l-Işsârât. thk. Ali Ucabî. 2 Cilt. Tahran: Miras-1 Mektûb, 2021.

Semerkandî, Şemsüddîn. Kıstâsu'l-Efkâr-Düşüncenin Kıstast-. çev. Necmettin Pehlivan. İstanbul: Türkiye Yazma Eserler Kurumu Başkanlığı, 1. Basım, 2014.

Semerkandî, Şemsüddin, İlmü'l-Âfâk ve'l-Enfüs, çev. Yusuf Okşar - İsmail Yörük. İstanbul: Türkiye Yazma Eserler Kurumu Başkanlığı, 1. Basım, 2020.

Tûsî, Nasîrüddin. Şerhư'l-İşârât (el-İşârât ve't-tenbîhât içerisinde). thk. Kerim Feyzî. 3 Cilt. Kum: Matbuat-i Dinî, 1383.

Türkmen, Ersan. “Şemsüddin Es-Semerkandî’nin Beşârâtu'l-Işŝarât Adlı Eserinde Kullandığı Şerh Metodu Ve Eserin İlahiyât Bölümünde Varlık Ve İlletleri Konusuna Yaklaşımı". Trabzon İlahiyat Dergisi 6/2 (2019), 231-256. 